\title{
Nota introdutória. A época $e$ as suas ideias
}

Moisés de Lemos Martins*

Toda a época tem um pensamento à sua altura, um pensamento que a diga em verdade. O "rei clandestino" (Simmel) da nossa época é o pensamento do mercado global e o pensamento da técnica. A nossa época resume-se, pois, a duas ideias: o mercado global, por um lado, e toda a espécie de tecnologias, por outro, sobretudo tecnologias da informação, que suportam o mercado, e biotecnologias, que reconvertem a vida humana num mundo ainda mais "admirável” do que a própria vida (Huxley).

As tecnologias da informação, ao mobilizarem a época, aceleraram o tempo histórico e criaram o mercado global (Sloterdijk: 2000) ${ }^{1}$. Esta criação significa, todavia, a crise permanente do humano, a qual é alçada a categoria dominante da cultura contemporânea. As tecnologias ligam globalmente os indivíduos em tempo real, criando neles o cérebro de que elas precisam, o de indivíduos empregáveis, competitivos e performantes no mercado, mas desarticulam-nos ao mesmo tempo como cidadãos, impondo-lhes um destino de ora em diante fragmentário, caótico e nomádico.

Por sua vez, as biotecnologias, fundindo o orgânico e o inorgânico, autotelizam a técnica e sonham uma nova criação, uma criação de híbridos, que correspondem a uma superação da própria vida humana, uma vida imaginariamente enriquecida e melhorada biotecnologicamente.

Com tecnologias da informação, que suportam o mercado global, e biotecnologias, que fantasiam melhorar a vida humana, na confluência umas e outras de "desejo, valor e simulacro" (Foucault, in Klossowski, 1997: 9), temos a crise da razão histórica, ou seja, a crise das grandes narrativas (Lyotard: 1979), e também a crise do narrador (Benjamin: 1992), com a consequente crise da verdade, e simultaneamente o "empo-

\footnotetext{
* Centro de Estudos Comunicação e Sociedade (CECS), Universidade do Minho. moiseslmartins@gmail.com

1 "O projecto da modernidade assenta [...] numa utopia cinética: a totalidade do movimento do mundo deve converter-se na execução do projecto que temos para ele. Progressivamente, os movimentos da nossa própria vida identificam-se com o movimento do mundo [...] O sujeito decisivo da modernidade é fazer natureza" (Sloterdijk, 2000 23).
} 
brecimento da experiência”, que se esgota em excitação, efervescência, espectáculo, euforia, simulacro, meros "guardiães do sono" da razão, como assinalou Guy Debord (1991: 16) ${ }^{2}$.

As representações do humano nas tecnologias da informação jogam com alguns efeitos diagnosticados pela análise crítica da modernidade. Estamos a pensar, por um lado, na transformação radical da nossa relação com a natureza e nas alterações profundas no aparelho de percepção, onde se misturam as águas de fenómenos simulacrais, queremos dizer, a alienação e a expropriação da socialidade, a imobilidade e a desterritorialização, a perda de consciência histórica e a dissolução da memória colectiva. E pensamos igualmente, por outro lado, nos fenómenos opostos de naturalização da cultura, intensificação dos laços sociais, localismo, tribalismo e hedonismo. Com efeito, cada vez mais as tecnologias nos dão conta da substituição progressiva de figuras planas como as de projecto, promessa, historicidade e finalidade, que na modernidade identificam o humano, pelas figuras côncavas da dobra, da prega, do requebro e do fractal, onde uma permanente hemorragia de sentido não pára de declinar a temática do fim, seja do fim da história e da verdade, seja do fim do simbólico e da mediação.

$\mathrm{Na}$ tecnologia, sobretudo nas tecnologias da informação e nas biotecnologias, decide-se hoje o humano. Quer isto dizer que o humano se decide na crise da época. A crise é desencadeada pelo autotelismo da técnica, uma autarcia de sentido, um pensamento de "meios sem fins" (Agamben: 1995), um messianismo sem telos, uma era de abundância e consumo fáusticos, com a excitação da hibridez, o seu sex-appeal, dirá Perniola (2004), que numa liga de orgânico e não orgânico, de humano e não humano, tanto configura os seres humanos como coisas, como projecta os objectos técnicos como animais.

Os primeiros capítulos deste número de Comunicação e Sociedade constituem uma reflexão alargada sobre a técnica na contemporaneidade. Seguem-se tematizações diversas de um conjunto de figurações tecnológicas. Os dois últimos capítulos interrogam o destino e a força da palavra, contrariando a ideia do seu declínio pelo advento da decantada civilização da imagem.

\section{Referências bibliográficas}

Agamben, Giorgio (1995), Moyens sans fin. Notes sur la politique. Paris: Payot \& Rivages.

Agamben, Giorgio (2000) [1978], Enfance et Histoire. Paris: Payot \& Rivages.

Baudrillard, Jean (1981), Simulacres et simulation. Paris: Galilée.

\footnotetext{
${ }^{2}$ A ideia de "crise da experiência" começa por ser referida em Benjamin no seu texto sobre "O narrador" e parece hoje em fase imparável pela aceleração tecnológica do nosso tempo. Agamben fala da impossibilidade em que nos encontramos, hoje, de nos apropriarmos da nossa condição propriamente histórica, o que torna "insuportável o nosso quotidiano" (Agamben, 2000: 20). Perniola, por sua vez, ao caracterizar a experiência contemporânea, introduz o conceito do "já sentido" e interroga-se sobre o sex appeal do inorgânico, que tem tanto de fascinante como de inquietante (Perniola, 1993 e 2004). Quanto a Baudrillard, conhecemos o seu conceito de realização do real como simulacro (Baudrillard, 1981).
} 
Benjamin, Walter, (1992) [1936-1939], «O narrador. Reflexões sobre a obra de Nicolai Lesskov», in Sobre arte, técnica, linguagem e política. Lisboa: Relógio d'Água, pp. 27-57.

Debord, Guy, (1991) [1967], A Sociedade do Espectáculo. Lisboa: Mobilis in Mobile.

Klossowski, Pierre (1997) [1970], La Monnaie vivante. Paris: Ed, Payot \& Rivages.

Lyotard, Jean-Fançois (1979), La Condition post-moderne. Paris: Minuit.

Perniola, Mário (1993) [1991], Do Sentir. Lisboa: Presença.

Pernioa, Mário (2004) [1994], O Sex Appeal do Inorgânico. Coimbra: Ariadne.

Sloterdijk, Peter (2000), La Mobilisation infinie. Christian Bourgois Ed. 